\title{
CHALLENGING DIRECTORS AND THE RULE IN FOSS v. HARBOTTLE
}

\author{
S. CHUMIR*
}

What right does an individual shareholder in a company have to challenge the qualification of a director or, even more important, the regularity of his election? Can he do anything if his votes are wrongly rejected or if a mentally incompenent man is sitting on the board of directors? There is a line of authority which would define these rights very narrowly and would insist on action by the company itself in such matters. "For many years it seems to have been settled that proceedings to question the regularity of the appointment of directors should be taken by the company and not by a shareholder on behalf of other shareholders."1 The principle has been even more broadly stated as precluding any interference at all by the courts "as a general rule, at least, to restrain the directors of a company from acting as such directors."' If these statements are correct they present an open invitation to either controlling directors or shareholders to manipulate elections and evade disqualification as long as they can prevent an action in the company's name.

Fortunately for the minority shareholder such views do not accurately represent the law, although in many instances they may present formidable hurdles to the enforcement of his rights. The extent of the difficulties which he will encounter depends upon whether he is challenging the qualification of a director or his election, which are substantially different matters. Most of the barriers will arise in actions involving procedural irregularities at elections. As to challenging the status of a director who has been disqualified, the shareholder's war has been virtually won, although a few battles remain to be fought. It is the purpose of this article, firstly, to examine the general principles applicable in these areas; secondly, to identify precisely the nature of the shareholder's rights involved in such matters; and, thirdly, to examine the relevant case law and thereby eliminate some prevailing misconceptions.

\section{GENERAL PRINCIPLES APPLICABLE}

Several reasons have been suggested for requiring action in the company's name. Firstly, it has been stated that the usurpation of the director's office is "an invasion of the rights of the corporation"3 for which the company is the proper plaintiff. Alternatively, it has been justified on the ground that this is an aspect of the company's internal management which is under the control of a majority of the shareholders:

If the majority are satisfied that the present board should remain in office until

the expiration of the statutory term of office no useful purpose would be served

- B.A. LC.B. (Alta.).

1 Fraser River Mining Co. v. Gallagher (1895), 5 B.C.R. 82, 103, per McCreight, J. This is accepted as good law in 4 C.E.D. (Western) 125 and 177 (2nd ed.).

2 Hattersley y Earl of Shelburne (1862), 31 L.J.Ch. 873, 880, per Kindersley, V.C.

3 Mozley v. Aiston (1947) 1 Ph. 790, 800, 41 E.R. 833, 837: Kelly v. Electrical Construction

Co. (1908), 16 O.L.R. 232, 234; Watt v. Commonwealth Petroleum Co., [1938| 4 D.L.R. 701, 707 (Alta. C.A.). 
by unseating them, for it would at once be in the power of the majority to restore them to office.4

In effect, these are merely restatements of the notorious rule in Foss v. Harbottle $e^{5}$ insofar as it relates to the director's position. The best known version of the rule is that formulated by Lord Davey in Burland v. Earle: ${ }^{\circ}$

It is an elementary principle of the law relating to joint stock companies that the court will not interfere with the internal management of companies acting within their powers and in fact has no jurisdiction 7 to do so. Again, it is clear law that in order to redress a wrong done to the company or to recover money or damages alleged to be due to the company, the action should primâ facie be brought by the company itself.

There can be no objection, insofar as these statements embody the common sense principle that in ordinary policy matters ${ }^{s}$ the majority rules, that "the company must be master in its own house." ${ }^{3}$ However, in injecting these rules into matters relating to the status and election of directors, some courts have completely overlooked the personal rights of the shareholder which are beyond the power of any majority to waive. When these rights are infringed the question is "not even within the general ambit of the rule [in Foss v. Harbottle]," 10 for they involve matters which are "ultra vires the majority of the shareholders."10a Thus, it is important to identify the nature of the personal rights involved in the usurpation of office by an unqualified or an irregularly elected director.

\section{PERSONAL RIGHTS}

Most of a shareholder's rights are contractual, although they may arise by virture of statute ${ }^{11}$ or the general law. ${ }^{12}$ In those jurisdictions where incorporation is effected by registration of a memorandum and

+ Kelly v. Electrical Construction Co., ante, n. 3, at 234, per Mullock, C.J. This is the "futllity" justification for the rule in Foss v. Harbottle, post, $n$. 5 . Why interfere if the majority can just repeat their acts? See MacDougall v. Gardiner (1875), Ch. D. 13 , 25 (C.A.).

5 (1843), 2 Hare 461, 67 E.R. 189. The rule is of primary importance in Canadian company law and has been raised in a number of recent decisions: e.g., McRae v. Western Ice Co. (1962), 38 W.W.R. (N.S.) 484 (S.C. B.C.): Schaffran v. Levinoff, [1962] O.W.N. 5; Ingre v. Maxwell (1964), 44 D.L.R. (2d) 764 (S.C. B.C.). See Gower, Modern Company Law 526ff. (2nd ed. 1957), and Wedderburn, Shareholders' Rights and the Rule in Foss v.Harbottle, [1957] Camb. L.J. 194 and [1958] Camb. L.J. 93. Despite Its significance. the rule has been completely neglected in Canadian legal writing.

6 [1902] A.C. 83, 93 (P.C.(Ont.C.A.)).

7 It is not always recognized that in a true internal management situation the courts will not hear the action even if brought by the company, since the proper forum to deal wot hear the action even if Coal Mines Ltd., [1926] 3 W.W.R. 378, 380 (B.C.C.A.); and Co. de Mayville v. Whitley, [1896] 1 Ch. 788, 807 (C.A.)

8 Most matters which the courts have held to fall within majority rule seem to be no more than policy matters involving the operation of the business. It is a matter of policy, for example, whether a company should sue a negligent director, since it may policy, for example, whether a company should sue a negligent director, since it may be to a company's long-run advantage not to enforce their rights: see Pavlides v.
Jensen, [1956] $1 \mathrm{Ch}$. 565; but not where the acts are fraudulent: Mason v. Harris (1879). 11 Ch. D. 97

- Australian Coal \& Shale Employer's Federation v. Smith (1938), N.S.W.S.R. 48, 56.

Australian Coal \& Shale Employer's Federation v. Smith (1938), N.S.W.S.R. 48, 56,
per Jordan, C.J., in a judgment which contains a most illuminating discussion on the nature of the rule.

10 Edwards v. Halliwell, [1950] 2 All E.R. 1064. 1067 (C.A.). Where a shareholder's personal rights are encroached upon, he can always bring action. This is a recognized exception rights are encroache ante, n. 13, at $529 \mathrm{ff}$. and cases cited there. Canadian courts have generally relled upon textbook statements not specifically acknowledging this as an generally relled upon textbook statements not specifically acknowledging this as an exception: e.g.. In re Pacific Coast Coal Mines Ltd., ante, n. 7 , at 383 . But they have
frequently appiled cases representative of the exception: e.g., Howarth v. Dench, [1942] 2 D.L.R. 177 (B.C.C.A.).

$10 a$ Kaye v. Croydon Tramways Co., [1898] 1 Ch. 358, 375 (C.A.), per Vaughan-Williams, L.J.

11 E.g., the right to inspect the balance sheet and auditor's report: Alberta Companies Act, R.S.A. 1955, c. 53, s. 123 .

12 . Alexander v. Automatic Telephone Co.. |1900! 2 Ch. 56 (C.A.). This right is statutory under the Dominion Companics Act, R.S.C. 1952, c. 53. S. 12 (8) 
articles of association ${ }^{13}$ those instruments form the basis of the contract, by virtue of a section in the relevant legislation providing that they shall "bind the company and the members thereof to the same extent as if they respectively had been signed and sealed by each member."14 The effect of this is to form a contract both between the shareholders inter se $e^{15}$ and between the company and the shareholder. ${ }^{16}$ But it is a contract of a strange kind, for it is "not an absolute, but a conditional contract,"17 which has been entered into subject to the possibility of the articles being altered ${ }^{18}$ and with the understanding that the majority is to prevail in most ordinary matters within the jurisdiction of the shareholders. ${ }^{10}$ Subject to this, the articles form the basis of the member's own rights in the company, which he may enforce personally in the courts. ${ }^{20}$

It is more difficult in principle to ascertain the source of the shareholder's rights in a letters patent company, since the nature of those companies themselves has not been adequately determined. ${ }^{21}$ Although there is no provision in the relevant statutes constituting the by-laws a contract in the same manner as for articles of association, it is only by virtue of agreement that a man becomes a shareholder; ${ }^{22}$ and it has been recognized that his rights are contractual in a letters patent company, as well. $^{23}$ At any rate, the same basic principles ${ }^{24}$ apply, and he has rights under the by-law which he may personally enforce ${ }^{25}-a$ fortiori if they are given special statutory force as well as being consensual.

Two different kinds of personal rights are involved in an action challenging a director's position.

\section{The Right to Have Only Properly Qualified and Elected Directors in Office.}

It would be a matter of some concern to a shareholder to see that only properly qualified men are managing the company in which he has invested his money. Those provisions in the articles which deal with dis-

13 Alberta, British Columbia, Newfoundland, Nova Scotia, and Saskatchewan. Companies in the other provinces and Dominion companies are incorporated by letters patent.

14 Alberta Companies Act, s. 28.

15 There have been dicta to the effect that "such rights can only be enforced by or against a member through the company, or ... liquidator": Welton v. Saffrey, [1897] A.C. 299,315 (H.L.), per Lord Herschell (in dissent on the main issue). But this was rejected in Rayfield' v. Hands, [1958] 2 W.L.R. 851 (Ch.) (action to require defendants [shareholders and directors] to bus plaintiff's shares under provisions in the articles).

10 Hickman v. Went, [1915] 1 Ch. 881, 884; Theatre Amusement Co. v. Stone (1914), 50 S.C.R. 32, 37.

17 Shuttleworth v. Cox Brothers \& Co., [1927] 2 K.B. 9, 16 (C.A.), per Bankes, L.J.

18 Alberta Companies Act, s. 52; Dominion Companies Act, ss. 92 and 93 (re alteration of by-laws).

10 Such matters are narrow indeed, since there is generally some provision in the articles delegating the management of the business to the directors (Alberta Companles Act, Table A, art. 55). The Dominion Act itself provides for this in ss. 84 and 92 . The provisions preclude any interference at all by the majority: Salmon v. Quin \& Axtens Ltd., [1909] 1 Ch. 311 (C.A.) (articles): Stephenson v. Vokes (1896), 27 O.R. 691 (letters patent). However, shareholders usually retain control over the electlon of directors and must do so under the Dominion Act, s. 88. Most important, they are able to ratify breaches of duty by the directors: Grant v. U.K. Switchback Ru. (1889), 40 Ch. D. 135 (C.A.).

20 Pender v. Lushington (1877), 6 Ch. D. 70. And see post.

21 See Fraser \& Stewart, Company Law of Canada $47 \mathrm{ff.}$ (5th ed. 1962).

22 Dominion Companies Act., s. 3(n), defines a "shareholder" as, inter alia, "every other person who agrees with the company to become a shareholder."

23 For the proposition that a valid by-law may operate as a contract between the shareholders and the company, see Fraser \& Stewart, ante, n. 21, at 618-19, and cases cited there.

24 Hence, any future reference to articles will include the case of by-laws as well.

25 Ante, n. 23. 
qualification ${ }^{26}$ usually cover such matters as undischarged bankruptcy, lunacy, and conviction for a criminal offence, all of which, if happening to a prospective director, would be strong indicia that he is unfit for office. Then again, a man who has a share qualification,"i particularly a large one, would usually take a more active interest in the business than one "who can, without loss to himself, play ducks and drakes with the company's property." ${ }^{28}$ Similiarly, in the case of elections, a member might have special interests which he wants protected by his candidate for office or he might have strong views about the suitability of a candidate. In either situation he would want to be able to influence the choice by his votes or his powers of persuasion.

Aside from those cases involving direct challenges to directors ${ }^{20}$ because of a defect in their qualifications or election, the law has recognized the interests of the shareholder in the director's office in diverse ways. Thus, it has been established generally that the articles are "a contract between all the shareholders as regards the directors," and that this will prevent a majority from removing a director unless so authorized by the article. ${ }^{31}$ Furthermore, when there has been a delegation of management to the directors, a majority cannot interfere, since the delegation is considered to be "for the protection of a minority of the shareholders." 32 Similarly, a shareholder may insist on his right to be a director. ${ }^{33}$ This is crucial, since it must be his rights in his capacity as a shareholder and not as a director which he is affirming. Otherwise, if it were a director who is not also a shareholder suing, it would be necessary to justify specific performance of a contract for services $^{34}$ where there is no mutuality, ${ }^{35}$ and where damages would be

26 Alberta Companies Act. Table A, art. 61. It is noteworthy that art. 61 provides, inter alia, for disqualification if the director is concerned in the profits of any contract with the company (with some exceptions). However, this result is often altered to allow such contracts, since Table $A$ is optional. The Dominion Companies Act does not contain a model set of by-laws, but by-laws usually contain provisions similar to those of art. 61: see Fraser \& Stewart, ante, n. 21, at 568 .

27 Alberta Companies Act, s. 84, states that if the articles require a share qualification it must be taken up within two months, or else the director is disqualified. Table A, art. 54, provides for a one-share qualification. However, under the Dominion Act, s. 86 (1), a director must have a qualification.

28 Archer's Case, [1892] 1 Ch. 322, 341 (C.A.), per Bowen, L.J.

29 See post.

30 Imperial Hydrophatic Hotel Co. v. Hampson (1883), 23 Ch.D. 1, 10 (C.A.), per Cotton, L.J.

31 Ibid. The articles generally provide for removal by special resolution (requiring a three-quarter majority and 21 days notice): Alberta Companies Act, s. 2 (ff) and threesion a simple majority: Alberta Companies appointment by Act, Table A, art. 68 . Under the Dominion Compansted by the shareholders before the for their removal; but, if not, they cannot be ousted by the sharehold
expiry of their term of office: Stephenson v. Vokes (1896), 27 O.R. 691.

32 Automatic Self-Cleansing Filter Syndicate v. Cuninghame, [1906] 2 Ch. 34, 38; Salmon v. 99 L.T. 524, 525 (Ch.).

33 Pulbrook v. Richmond Consolidated Mining Co. (1878), 9 Ch. D. 610; Howarth v. Dench, [1942] 2 D.I.R. 177 (B.C.C.A.).

34 Haues v. Bristol Plant Hire Ltd, [1957] 1 W.L.R. 499 (Ch.), decided that the position Has one for services, although allowing specific performance on the ground that the was one for services, although allowing specific performance on the ground that the director had a special proprietary interest in the office. Since the latter contention is open to attack, the recognition of the position as one for services may have important consequences when a director does not have a share qualification and desires specific performance of a service agreement. If he were a shareholder, he could claim on his rights

35 For the rule that specific performance will not be awarded where there is no mutuality, see Ashburner, Principles of Equity 404-05 (2nd ed. 1933). 
adequate. ${ }^{36}$ A shareholder, in seeking specific performance, is merely enforcing his right to have the articles observed..$^{37}$

The extent of the shareholders' rights in such matters depends upon the contract in the articles. Insofar as they make provision for disqualification "if the company by its agents permits an unqualified person to act as director, its conduct may constitute a breach by the company of its obligation to its shareholders to abide by the Articles of Association." 38 The same principle has been applied to elections. ${ }^{30}$ This right to have only properly qualified and elected directors in office is the first right of which the law has taken cognizance in this area, although as we shall see it has not always been enforced.

\section{The Right to Have Proper Procedures.}

There is another right which arises only in the case of an irregular election-the right to insist on the proper procedures provided by the articles for convening and conducting meetings. However, as every company lawyer knows, not every procedural error will justify a personal action. In refusing to impeach every irregularity, the courts have been motivated by the practical consideration that "they are not all lawyers who attend these meetings [and] nothing can be more likely than that there should be something more or less irregular done at them." can it have been the intention of the parties contracting that every slip should enable a resolution to be attacked. On the other hand, neither can it be contended that there was no intention that procedures be fairly strictly followed, for they have been established for the protection of the shareholder. ${ }^{10 a}$ They are in many ways just as much the essence of the agreement as the right to share in the profits, and the man who is deprived of his rights at meetings may see his profits dwindle in direct proportion. Any pious hope that laxity in procedural safeguards will not lead to abuse is, as Dr. Johnson said of second marriage, the "triumph of hope over experience."

Obviously, the need is for some principle which disregards mere trifles (e.g., the order of business), ${ }^{41}$ yet hits out at breaches of rules designed for shareholders' protection. An overwhelming number of cases raising procedural issues has resulted in action on this principle. However, there is a diametrically opposed series of cases, relatively small in number, which purports to deny the shareholder's right to have the articles observed on procedural matters.

36 See id. at 390 .

37 There is some doubt as to what extent a shareholder can insist on provisions in the articles concerning the director, since the rule is that the articles are a contract with him only in his capacity as member (Hickman v. Kent, ante, $n$. 16), and not as director (Beattie v. E. \& F. Beattie Ltd., [1938] Ch. 708 (C.A.)). However, it is only common sense that many provisions relating to the directors are inserted to protect the shareholder (ante, notes 31 and 32 ), and it would be unrealistic to say that they do not affect a member in his capacity as member. But see Browne v. La Trinidad Ltd., (1888), 37 Ch. D. 1, 14 (C.A.): and the Beattie case, at $720 \mathrm{ff}$.

38 Australian Coal \& Shale Employer's Federation v. Smith, ante, n. 9, per Jordan, C.J., at 57.

89 Ibid. And see post.

40 MacDougall v. Gardiner (1875), 1 Ch. D. 13, 25, per Mellish, L.J.

$40 a$ See Hayes v. Miron, [1957] Que. Q.B. 538, 554.

11 But even the order of business may be tampered with or matters done in such haste as to prejudice a shareholder. Cf. Armstrong v. McGibbon (1905), 29 Que. S. C. 289 aff'd (1906), 15 Que, K. B, 345, where business was rushed through before the plaintiff shareholder, who had given notice that he would be ten minutes late, arrived. The resolutions passed thereat were avolded. See post. 
The locus classicus of the latter group of cases is MacDougall v. Gardiner. ${ }^{12}$ The statement of principle therein, by Mellish, L.J., is one of the most frequently cited passages in all of company law:

If the thing complained of is a thing which in substance the majority of the company are entitled to do, or if something has been done irregularly which the majority of the company are entitled to do regularly, or if something has been done illegally which the majority of the company are entitled to do legally, there can be no use in having a litigation about it, the ultimate end of which is only that a meeting has to be called, and then ultimately the majority gets its wishes. ${ }^{43}$

This statement has been interpreted by the authorities in two ways: firsty, that, if the nature of the resolution ${ }^{4 t}$ is such that a simple majority ${ }^{45}$ will prevail, then no irregularity will vitiate it; and, alternatively, that the nature of the breach itself must be of a kind which the majority are entitled to waive (i.e. a mere irregularity). The former approach emphasizes the type of resolution; the latter assesses the type of irregularity.

In MacDougall v. Gardiner ${ }^{46}$ itself, the court apparently ${ }^{47}$ adopted the first view; and refused to interfere where the chairman had improperly refused to allow a poll on a resolution to adjourn, since this was a matter which a majority may properly determine. The ruling was followed in Cotter v. National Union of Seamen, ${ }^{48}$ where the court declined to interfere at the instance of an individual "merely because the meeting at which the resolution was passed was not properly convened or because there was some impropriety in the conduct of the meeting itself."19 The alleged irregularities were that improperly appointed delegates:0 $^{i 0}$ were allowed to vote and that no notice was given of certain business considered at the meeting.:11 Similiarly, in Pelech v. Ukrainian Mutual Benefit Assn.:2 the failure to give notice of a proposed increase in the dues of the association did not justify a personal action, because "the raising or lowing of dues . . . is a matter of internal management within the control of the members." ${ }^{33}$ Indeed, McGillivray, J.A., in a

42 (1875), 1 Ch. D. 13 (C.A.).

$43 \mathrm{Id}$. at 25 . This is, to repeat, the "futility" Justification for the rule in Foss v. Harbottle, ante, notes 4 and 5.

44 I.e., If it is an ordinary resolution on which the majority rules. Nothing appears to turn on the nature of the business itself in this line of cases, so long as the majority may properly pass the resolution. If it were a matter of the importance of the business, surely the election of directors must be considered essential; yet, procedural breaches have been allowed in some of these cases: see post.

45 If a special majority is required to pass the resolution (e.g., a special resolution) then a member may attack it, because to deny him the right would be equivalent to allowing a bare majority to do the act by refusing the use of the company's name: Baillie v. Oriental Telephone Co., [1915] 1 Ch. 503 (C.A.).

40 Ante, n. 42.

47 The decision is unsatisfactory on its fact, in light of the common law right to demand a poll: Campbell v. Maud (1835), 5 Ad. \& El. 865, 111 E.R. 1394; $R$. v. The Wimbledon Board (1882) 8 Q.B.D. 459. Although the court clearly felt that the taking of a poll was "internal management" it is uncertain how much the decision turned on the fact that the plaintiffs had already obtained control of the company and the court was that the plaintiffs had already obtained control of the company and the court was reluctant to grant a declaration on the poll issue where no consequential relief was asked: see the MacDougall case, ante, $n$. 42, at 27 . At any rate, the court did con-
template an instance of this kind where "the majority are abusing their powers and are depriving the minority of their rights," in which case the court would interfere: see the McDougall case, at 25-26.

48 [1929] 2 Ch. 58 (C.A.).

$10 \mathrm{Id}$. at 70 , per Romer, $\mathbf{J}$.

so The nature of the irregularities appears in the argument of counsel, id. at 88 .

51 The use of union funds as a loan to the "Miner's Non-Political Movement" and notification of a suspension from office by the general president of two of the plaintiffs.

$52[1940$ ] 4 D.L.R. 342 (Man. K.B.). This case and the Cotter case, ante, n. 48, show that the rule in Foss v. Harbottle extends to any society which can sue or be sued in its own name.

63 Id. at 346, per McPherson, C.J.K.B. A particularly disturbing decision since the court found as a matter of fact that (1) the "question effected [sic] directly the solvency of the society," (2) members were directly affected, and (3) officials had deliberately withheld information because they expected opposition to develop: see at 345-346. Cf. Edwards v. Halliwell, [1950] 2 All E.R. 1064 (C.A.) 
decision of the Appellate Division of the Supreme Court of Alberta has gone so far as to state that:

The voting, the appointment of scrutineers and the recording of votes are all matters which if done regularly could not be questioned as being beyond the powers of the company. If done irregularly the wrong flowing from the irregularity is a wrong to the company and not to the plaintiff or other individual shareholders and so it is the company which has the cause of action."is

In light of this statement one might wonder if it is the conscious policy of the law to encourage manipulation and trickery at company meetings.

The authorities yield a negative answer, and a very resounding one, to this problem. For every case classifying the conduct of the meeting as a matter of internal management there are numerous others establishing personally-enforceable rights in this sphere: the right to be heard, ${ }^{\text {s5 }}$ to move proper amendments to resolutions, ${ }^{, 6}$ to have the chairman correctly determine the sense of the meeting, ${ }^{57}$ to have "disinterested" scrutineers, ${ }^{, *}$ to have votes recorded, ${ }^{30}$ and to prevent improper votes from being used. ${ }^{\circ 0}$ For every decision like Pelech v. Ukrainian Mutual Benefit Assn.". there is an overwhelming number of authorities upsetting resolutions in relation to which there has been a complete failure to give notice, ${ }^{62}$ insufficient notice, ${ }^{63}$ and even a sending out of notice without the authority of the board of directors. ${ }^{64}$ And in the notice cases there is no indication, other than in the Pelech case, that the nature of the resolution is the critical factor. ${ }^{0.5}$ Surely, the individual right to take part in company affairs is behind these decisions.

This is confirmed by the locus classicus of this line of thought, Pender v. Lushington, "io decided only two years after MacDougall v. Gardiner. ${ }^{67}$ The plaintiff had been improperly denied the right to vote and sought redress. Jessell, M.R., in a famous passage, stated:

This is an action by Mr. Pender for himself. He is a member of the company, and whether he votes with the majority or the minority he is entitled to have his vote recorded-an individual right in respect of which he has a right to sue. That has nothing to do with the question like that raised in Foss v. Harbottle ... that is a right of property belonging to my interest in this company . . . 88

If a vote is "right of property" which a company may not directly deny a shareholder, should it be able to do so indirectly by refusing a poll or

s4 Watt v. Commonwealth Petroleum Ltd., [1938] 4 D.L.R. 701,707. Semble, MacDougall v. Gardiner, (1875) 1 Ch. D. 13, 22.

is Wall v. London \& Northern Assets Corp., [1898] 2 Ch. 469, 408-81 (C.A.); Const v. Harris (1823), Turn. \& R. 496, 37 E.R. 1191.

5 H Henderson v. Bank of Australasia (1890), 45 Ch. D. 330 (C.A.).

i7 National Dwelling Society v. Sykes, [1894] 3 Ch. 159; Second Consolidated Trust Ltd. V. Ceylon Amalgamated Tea \& Rubber Estates Ltd., [1943] 2 All E.R. 567 (C.A.).

is Dickson v. McMurray (1881), 28 Gr. 533.

is Pender v. Lushington (1877), $6 \mathrm{Ch}$. D. 70.

iil Davidson v. Grange (1884), 4 Gr. 377; Shavo v. Tati Concessions Ltd., [1913] 1 Ch. 292.

(1) [1940] 4 D.L.R. 342 (Man. Q.B.). See also Exchange Auto Parts Ltd. v. Furby (1963), 41 W.W.R. (N.S.) 678 (Man. C.A.); and In re Pacific Coast Coal Mines Ltd., [1926] 3 W.W.R. (N.S.) 378 (B.C.C.A.)

G: Alexander v. Simpson (1889), $43 \mathrm{Ch}$. D. 139. The common law rule applied even when the omission was accidental but there is generally a provision in the articles that such accidental omission will not vitiate the resolution.

:a Kaye v. Croydon Tramways Co., [1898] 1 Ch. 358 (C.A.): Garvie v. Axmith, [1962] O.R. 65. And see the many cases cited in Fraser \& stewart, Company Law of Canada 650-52 (5th ed. 1962).

04 Wood v. Pan-American Investment Ltd. (1961), 28 D.L.R. (2d) 703 (S.C.B.C.): Re State of Wyoming Syndicate, [1901] 2 Ch. 431. But cf. Southern Counties Deposit Bank v.

6.) Although it is "in a special way necessary that notice should be given when the proposed business is the pecuniary advantage of a director": In re National Health Assn. (Galloway's Case). [1948] 2 W.W.R. 329, 337 (S.C.B.C.). Can it be any less important when the election of such directors is involved?

no (1877), 6 Ch. D. 70.

nT (1875), 1 Ch. D. 13 (C.A.).

6. Ante, n. 66, at $80-81$. (Italics supplied.) 
by phrasing the notice in such a manner that it fails to shake the shareholder out of his usual disdain for attending meetings? Most, but not all, of the cases, as we have seen, answer in the negative. Consider particularly Watson v. Barrett, ${ }^{69}$ where a group of shareholders was left standing in a lobby while the controllers proceeded to elect a board of directors in a locked inner office. The court refused to interfere, on the ground that this was a question of internal management which could be regularized by passing fresh resolutions.

This is a puzzling phenomenon. On one hand, the reports are replete with decisions allowing personal actions on the basis of irregularities, many with no discussion at all of Foss v. Harbottle or MacDougall v. Gardiner. Lined up on the other side is a compact body of cases, lying not merely in reserve to deal with trifling matters or special situations, but containing statements wide enough to render the opposition totally ineffective.

If it were a matter of selecting one line to the exclusion of the other, simple numerical superiority would militate against the latter. This would have the merit of giving some meaning to the contractual provisions in the articles regarding meetings, and at the same time would not conflict with the principle in MacDougall v. Gardiner, since the case is open to this broad interpretation. ${ }^{i 0}$ However, until some higher court settles the matter, the most that can be said is that a shareholder has substantial personal rights in this area which he will usually be able to enforce, subject to the possibility that the courts will invoke the alternative authorities available to them. Certain policy matters which might determine the choice will be discussed later. For the time being, it will be sufficient to have established this second prima facie right of the shareholder involved in a disputed election of directors and to move on to examine the decisions in which shareholders have attempted to challenge a director's position.

\section{CHALLENGING THE STATUS OF DIRECTORS}

It will be convenient to deal briefly with actions to challenge the status of a director before plunging into the more difficult subject of elections. Aside from the ever-present possibility of some technicality ${ }^{70 a}$ based on Foss v. Harbottle being raised, it is well settled that the disqualification of a director for a breach of the articles "give[s] a right of action on the part of any shareholder for a declaration of such disqualification." " Hence, where the articles provided for disqualification when a director contracted with the company, ${ }^{72}$ or made false statements in the

69 (1929), 41 B.C.R. 478 . The decision must be wrong.

70 I.e., the second interpretation, ante.

70a There is a substantial number of technical defences associated with Foss v. Harbottle, and one can never be certain whether a court may choose to accept them even on this issue: e.g., want of parties (Kent v. Jackson (1851) 14 Beav. 367, 51 E.R. 328), acquiescence (Towers v. African Tug Co. [1904] 1 Ch. 558 (C.A.)).

1 Theatre Amusements Co, v. Stone (1915), 50 S.C.R. 32, headnote. Any salary paid while the director was disqualified can be recovered as money paid under a mistake of fact: In re the Bodega Ltd., [1904] $1 \mathrm{Ch} .276$.

72 Bodega case, ibid. 
company accounts, ${ }^{i 3}$ personal actions challenging the directors have been allowed; and the same is true of actions based upon a failure either to own sufficient qualifying shares at the time of election ${ }^{74}$ or to obtain them within the time allowed.i5 The action is usually based upon the first right previously mentioned, the right to "insist upon the articles being observed"is in relation to the qualifications of directors, although it may be based upon statute. ${ }^{i i}$ Since it might be argued that only when the disqualification is statutory do personal rights arise,$^{78}$ it is important to emphasize that the disqualification of the directors for contracting with the company in Theatre Amusement Co. v. Stone ${ }^{70}$ ensued from breach of an article of the company, not a statutory provision. Thus, the strong views of the Supreme Court of Canada ${ }^{80}$ on the binding nature of the articles cannot be eroded by this side wind.

When a director comes within any of the disqualifying provisions he "ipso facto ceases to be a director and it is not necessary that there should be any resolution to remove him;"'st and, therefore, the board may simply exclude him. He may, of course, bring a personal action to determine whether he falls within the scope of the article; but, if he does so fall, his action will fail on its merits. ${ }^{* 2}$ Kekewich, J., suggested in one case $^{83}$ that, where the directors held a meeting to declare the office vacant, the disqualified director was entitled to be present; for "he might have made a plausible speech, and might, if he were as clever an advocate as a cyclist, have won over the director." ${ }^{4}$ On principle, this view is untenable, because in none of the instances of disqualification is there "any means by which the directors can condone the offence"; ${ }^{85}$ and, since a meeting is not necessary, a procedural fault should not vitiate the disqualification even where one is held.

73 Wheeler v. Freame \& Alberta Farmer's Co. Ltd. (1914), 7 W.W.R. 191 (S.C. Alta.). The court considered Foss $v$. Harbottle relevant in this situation, but evaded it on the ground that this was a company formed under special act in which the public had a special interest, since provinclal aid was given. This, however, does not seem necessary to the decision in light of other authority on the matter. The court also had doubts that the headnote in Theatre Amusement Co. v. Stone, ante, n. 71, "represented the actual decision made" since "It is not clear that there was any judgment given disqualifying the director." However, the Supreme Court of Canada in the Stone case clearly treated the directors as disqualified and made them disgorge salaries which they had recelved.

i4 Channel Collieries Trust Ltd. v. Dover, [1914] 2 Ch. 506 (C.A.).

i. Holmes v. Keyes, [1959] Ch. 199 (C.A.) (action fatled on merits, but no objection to form).

io Theatre Amusement Co. v. Stone (1915), 50 S.C.R. 32, 37.

if E.g., where it is a statutory provision which provides for disqualification, as in the Alberta Companies Act, s. 84, in relation to share qualifications. This was the case in Holmes v. Keyes, ante, n. 75. However, there seems no reason why a statutory provision should be considered more imperative in this area than the articles. The distinction has not in the notice cases where some are based on statutory provisions (e.g.. Kaye v. Croydon Tramways Ltd., [1898] 1 Ch. 358 (C.A.), concerning s. 71 of the (e.B.. Kaye v. Croydon Tramways Ltd., [1898] 1 Ch. 358 (C.A.), concerning s. 71 of the notice in the articles (e.g., Baillie v. Oriental Telephones Co., [1915] 1 Ch. 503 (C.A.)). 78 Ibid.

70 (1915), 50 S.C.R. 32.

80 Id. at 36-37, per Duff, J., (as he then was):

The articles of association are binding upon the company, the directors and the The articles of association are binding upon the company, the directors and the shareholders, until changed in accordance with the law. So long as they remain in by some conduct of his own, to insist upon the articles being observed by the company and the directors of the company. Of this right he cannot be deprived by the action of any majority. In truth, the articles of association constitute a contract between the company and the shareholders which every shareholder is entitled to insist upon being carried out.

81 Browne v. La Trinidad (1887), 37 Ch. D. 1, 12 (C.A.), per Cotton, L.J.

82 Astley v. New Tivoli, Ltd., [1899] 1 Ch. D. 151.

83 Turnbull v. The West Riding Athletic Club, Leeds, Ltd. (1894), 70 L.T. 92.

84 Id. at 94 .

8.5 In re the Bodega L.td., [1904| 1 Ch. 276, 283, per Farwell, J. 


\section{IRREGULAR ELECTIONS}

In this area there are again two competing lines of cases, one allowing a shareholder to attack an irregular election of directors, the other requiring action by the company. In fact, this area involves the same question of procedural irregularity discussed earlier, but the question arises this time in the context of the election of directors. The issue is whether the operative factor is the nature of the resolution or the nature of the procedural defect-i.e., whether the first or second interpretation of the principle in MacDougall v. Gardiner ${ }^{30}$ is correct. Three Canadian cases $^{87}$ have regarded the nature of the resolution to be the deciding factor, and have held that, since a majority of shareholders may elect a director, they may also disregard procedural irregularities at such an election. In order to assess the strength of these decisions it will be useful to look at the unsatisfactory nature of the English cases which first suggested that having improperly qualified or elected directors infringes only the rights of the company.

\section{Origin of the View.}

The earliest relevant case in which shareholders have sought to restrain directors from acting was Mozley v. Alston. ${ }^{88}$ An action was brought by two shareholders "in their individual characters" against the company and twelve directors, alleging that according to the true construction of the company's Act ${ }^{80}$ one third of the directors were supposed to retire "by balloting or agreement amongst themselves," but that they had refused either to retire or to agree which of them should retire, despite the express wish of the majority of the shareholders. ${ }^{90}$ The court refused to restrain the directors on three grounds: firstly, that the action should have been representative instead of personal, if it would lie at all; ${ }^{91}$ secondly, that the action could have been brought in the company's name, since the plaintiffs specifically alleged that "a large majority of the shareholders are of the same opinion with them"; 92 and, thirdly, Lord Cottenham doubted that a Court of Equity had jurisdiction to determine the validity of the directors' title, since the interpretation of the company's Act was a "pure question of law" and a "preliminary question which must be decided before this Court can make any decrees." ground has been removed by passage of the Judicature Acts. ${ }^{04}$ The second might seem to be compelling, since it is desirable for the company

80 Ante, p. 101.

87 Post, pp. 106-107. Watson v. Barrett (1929), 41 B.C.R. 478, is probably too extreme to be considered sound authority and, hence, is excluded.

88 (1847), 1 Ph. 790, 41 E.R. 833.

89 The company was incorporated by special Act of Parliament.

o0 A similar problem could occur today: e.g., in regard to an article similar to that in the English Companies Act, Table A, art. 90, which provides for directors who were appointed on the same day to decide which shall retire first "by lot."

01 This is one of the requirements when a shareholder is suing to enforce a right residing in a company, and not himself personally; and is known as a "derivative" action in the United States: see Gower. Modern Company Law 531 (2nd ed. 1957); and Wedderburn, Shareholders' Rights and the Rule in Foss v. Harbottle, [1957] Camb. L.J. 194, 205. But if the right is a "personal" one it justifies a personal action: Pender v. Lushington (1877), 6 Ch. D. 70 .

02 (1847), 1 Ph. 790, 800, 41 E.R. 833, 837. Another requirement of the rule in Foss v. Harbottle, where a shareholder is suing on a wrong to the company, is that he must allege in his pleadings facts which show that it would be idle to apply to the company to take action. The exact format is uncertain, but the latest Canadian cases seem to be less exacting in their requirements: see MacRae v. Western Ice (1962), 38 W.W.R. (N.S.) 484 (S.C.B.C.); and Ingre v. Maxwell (1964), 44 D.L.R. (2d) 764 (S.C.B.C.). At any rate, this requirement also disappears if we view the action as personal.

o3 (1847), $1 \mathrm{Ph} .790,802,41$ E.R. 833, 838 .

D4 See the Judicature Act, R.S.A. 1955, c. 164, s. 32. 
to bring the action where it is clearly possible; but this objection must fail if the wrong is personal (as it is).$^{93}$ The first objection also disappears if the wrong is personal.

Although Mozley v. Alston is frequently cited for the general proposition that the courts will not interfere in the internal affairs of companies; it has only been applied on one of the subsequent "director" cases in England, and is unlikely to be followed on similar facts since it involves a matter more akin to status ${ }^{06}$ than to an election.

The one English exception is Hattersley v. Earl of Shelburne, ${ }^{97}$ in which Mozley v. Alston was relied upon as authority "that the Court will not interfere, as a general rule at least, to restrain the directors of a company from acting as such directors" ${ }^{\prime 8}$ on the ground that the shareholders could remove them at a meeting. This decision, too, is doubtfull on its facts. It concerned a challenge to the position of several directors appointed under an ultra vires agreement. Since the agreement was ultra vires, it should follow that the appointment of directors pursuant thereto would be ultra vires as well, but the court held that the shareholders could not maintain the action. ${ }^{99}$ Again, construing it as a question of status, it would probably be decided differently today.

It is tempting to distinguish these cases as instances where the majority had the means of setting the company in motion, but this is immaterial where the right is personal. They may, perhaps, be explained as cases in which the court exercised its discretion to refuse an injunction on the ground that "granting the injunction may be more detrimental to the interests of the parties than refusing the injunction." 100 At any rate, they are meagre authority upon which to hold that proceedings to question the regularity of the appointment of directors should be taken by the company, and not by the shareholder on behalf of other shareholders.

They have, however, been accepted as authority for this proposition by some Canadian ${ }^{101}$ courts, which have also taken at face value certain opinions that the usurpation of office is an "invasion of the rights of the company" only. This view was first adopted in Canada in 1895 in Fraser River Mining Co. v. Gallagher, ${ }^{102}$ and reiterated in Kelly v. Electrical Construction Co. ${ }^{103}$ and Watt v. Commonwealth Petroleum Ltd. ${ }^{104}$ all of which refused to allow shareholders to upset irregular elections. The nature of the irregularity in the Fraser River case does not appear in the report, but in the Kelly case the plaintiff's proxy votes had been improperly (although apparently honestly) rejected. In the Watt case, not

os Ante, notes 91 and 92.

o6 Ante, p. 103.

97 (1862), 31 L.J. Ch. 873.

98 Id. at 880 , per Kindersley, V.C. (italics supplied).

99 Note that the action here was representative, removing the first objection in Mozley v. Alston, ante, n. 91

100 Ante, n. 98. See also Mozley v. Alston, ante, n. 91. Both courts seemed to be concerned that granting an injunction might leave the company without a governing body. But in Mozley v. Alston there were six other directors besides the twelve who were challenged.

101 The principle does not seem to have been applied in any of the subsequent English cases, although there is a dictum in MacDougall v, Gardiner (1875), 1 Ch. D. 13, 25, per Mellish. L.J., that the "bill must be flled in the name of the company" where "some
directors may have been irregularly appointed." See, also, In re Moore (1857), 14 U.C.R. 365, where a Canadian court was uncertain about the form of action, but decided the case on the basis of acquiescence.

102 (1895), 5 B.C.R. 82.

103 (1908), 16 O.L.R. 232

$104[1938]$ \& D.L.R. 701 (Alta. C.A.). 
only was there a "wrongful and illegal recording"105 of votes; but, in addition, one of the defendants who was elected a director acted as a scrutineer.

These cases clash head-on with a mountain of opposing decisions. The conflict is not merely one of principle; but, in some instances, one of facts. Thus, one of the grounds for upsetting the election in Dickson v. McMurray ${ }^{106}$ was that one of the candidates had acted as a scrutineer; and in Johnson v. Hall, ${ }^{107}$ as well as other cases, the improper rejection of proxy votes enabled a shareholder suing personally to attack the election.

It does not seem unreasonable to suggest, even on the basis of numerical superiority alone, that, prima facie, any breach of the procedural requirements in the articles will justify a personal action. ${ }^{108}$ This is fortified by both forms of personal right ${ }^{109}$ discussed earlier: the right to have provisions in the articles concerning the directors adhered to and the right to prevent procedural hanky-panky. The many cases allowing such actions may be grouped under five headings, although such headings are by no means exhaustive. In fact, they may be considered to be general instances in which courts will interfere at the behest of individuals regardless of the nature of the business or resolution involved.

\section{INSTANCES WHERE ACTION ALLOWED}

\section{Improper Rejection of Votes.}

From the very nature of elections, this is a common occurence, particularly with proxy voting. Thus, personal actions ${ }^{110}$ have been allowed when proxy votes have been wrongly refused ${ }^{111}$ or the right to vote at all has been challenged.112

\section{Improper Allowance of Votes.}

This is merely the corollary of the first class, and has justified actions where improperly executed proxies have been used, ${ }^{113}$ where there has been a "manufacture of illegal votes," 114 or where persons other than those registered have been allowed to vote. ${ }^{115}$ It is particularly difficult to

105 This appears in the pleadings, id. at 703 .

106 (1881), 28 Gr. 533.

107 (1957), 10 D.L.R. (2d) 243 (S.C.B.C.).

108 There will generally be no question that the company can bring the action: e.8., British Absestos Co. v. Boyd, [1903] 2 Ch. 439 (action by both company and representative): Legion Oils Ltd. v. Barron (No. 2) (1956), 2 D.L.R. 505 (S.C. Alta.) (company joined in what appears to be a personal action). But there may be some dispute over who has in what appears to be a personal action). But there may be some dispute over who has Batras, [1891] 2 Ch. 386 (dispute between factions of directors to use name): Colonial Assurance Co. v. Smith (1912), 2 W.W.R. 699 (majority of shareholders allowed to use company name).

109 See esp. Australian Coal \& Shale Employer's Fedn. v. Smith (1938), N.S.W.S.R. 48, 56. 110 See the curious case of Fremont Canning Co. v. Wall, [1941] O.R. 379 (C.A.), where relief was refused but the form of the action by shareholders was not criticized.

111 Cousins v. International Brick Co., [1931] 2 Ch. 90 (C.A.); Colonial Gold Reef Ltd. v. Free State Rand, Ltd., [1941] 1 Ch. 382; Johnson v. Hall (1957), 10 D.L.R. (2d) 243 (S.C.B.C).

112 Sasko-Wainwright Oil \& Gas Ltd. v. Old Stettler Oil Ltd. (1956-57), 20. W.W.R. (N.S.) 613 (Alta. C.A.) (plaintiff not allowed to vote shares held in "escrow"); see, also. Tough Oakes Gold Mines Ltd. v. Foster (1917). 34 D.L.R. 748 (S.C. Ont.).

113 Sadgrove v. Bryden, [1907] 1 Ch. 318 (representative action, but failed on merits). See Harben v. Phillips (1883), 23 Ch. D. 14 (C.A.) (court refused to force director on Harben v. Phillips (1883), 23 Ch. D. 14 (C.A.) (court refused to force dides): and Shaw v. Tati Concessions Ltd., [1913] $1 \mathrm{Ch}$. 292 (representative action allowed to restrain voting of proxies not lodged with company in time).

114 Davidson v. Grange (1854), 4 Gr. 377. See Dominion Royalty Corp. v. Holborn (1932), 41 O.W.N. 288.

116 Dickson v. McMurray (1881), 28 Gr. 533. 
reconcile Kelly v. Electrical Construction Co. ${ }^{116}$ and Watt v. Commonwealth Petroleum Ltd. ${ }^{117}$ with this and the former category.

\section{Mala Fides.}

It is an overriding principle of company law that directors must act bona fide.

... [T] They must act not only not mala fide but uberrimae fidei. The powers must be exercised for the purposes for which they were intended and if the directors use their powers otherwise, certainly if it is for their own advantage, they will be restrained by a Court or their actions declared a nullity.11s

In the previous classes we have been assuming that the acts were done honestly; but if there has been fraud, ${ }^{110}$ bad faith $^{120}$ or misrepresentation, ${ }^{121}$ or even a strong chance of $i^{122}$ in the voting or the conduct of the election, that election will be avoided. Thus, the chairman must act judicially in conducting proceedings ${ }^{123}$ and in determining the validity of proxies $^{124}$ or other votes ${ }^{125}$ tendered. Furthermore, a candidate may not also be a scrutineer, since his duty is "to some extent a judicial one," and there is "no plainer instance of conflict between interest and duty."120 When a shareholder has given notice that he will be ten minutes late and an election is held in haste before he arrives, the election cannot stand. ${ }^{127}$

\section{Notice and the Right to be Heard.}

It is another cardinal rule that failure to give a shareholder proper notice of meetings and the business to be transacted thereat will vitiate the proceedings. ${ }^{128}$ Thus, the notice must indicate that an election of directors will take place, or else the election will be voidable. ${ }^{129}$ This appears to be part of a wider policy of the law which is designed to provide the maximum opportunity for ascertaining the views of the shareholders by insuring that they are informed of meetings and have the right to be heard, ${ }^{130}$ to move amendments to resolutions, ${ }^{131}$ and to nominate their own candidate for director as long as they give the proper notice required by the articles. ${ }^{132}$ Analogous to this is the right to have decisions taken only when there is a proper quorum. ${ }^{133}$

116 (1908), 16 O.L.R. 232.

117 [1938] 4 D.L.R. 701 (Alta. C.A.).

118 Legion Oils Ltd. v. Barron (1956), 2 D.L.R. (2d) 505, 516, per Cairns, J.

110 Davidson v. Grange, ante, n. 114.

120 Johnson v. Hall (1957), 10 D.L.R. (2d) 243, 247 (S.C.B.C.); and see Armstrong v. McGibbon (1906), 29 R.J. 289, (1906), 15 Que. K.B. 345.

121 Dominion Royalty Corp. v. Holborn, ante, n. 114.

122 E.g.: Dickson v. McMurray, ante, n. 115.

123 See, generally, Second Consolidated Trust v. Ceylon Amalgamated Estates, [1943] 2 All E.R. 567 (C.A.); Re Lemay Ltd. (1924), 26 O.W.N. 443.

124 Johnson v. Hall, ante, n. 120.

125 Bleuchel v. Prefabricated Bldg. Ltd., [1945] 2 W.W.R. 309 (S.C.B.C.) (action for damages for improper rejection of vote on grounds that voter was an enemy alien).

120 Dickson v. McMurray (1881), 28 Gr. 533. Cf. Watt v. Commonwealth Petroleum, [1938] 4 D.L.R. 701 (Alta. C.A.).

127 Armstrong v. McGibbon, ante, n. 120.

128 Ante, n. 63.

120 Milot v. Perrault (1886), 12 Que. L.R. 193; Spencer v. Kennedy, [1926] 1 Ch. 125; Batcheller \& Sons Ltd. v. Batcheller, [1945] i Ch. 169. See Choppington Collieries Ltd. v. Johnson, [1944] 1 All E.R. 762 (Ch.) (notice held sufficient).

130 Ante, n. 55.

131 Henderson v. Bank of Australasia (1890), 45 Ch. D. 330 (C.A.).

132 Catesby v. Burnett, [1916] 2 Ch. 325.

133 Doig v. Mathews (1916), 25 D.L.R. 732 (S.C.B.C.) (no ojection to representative action, although court refused interim injunction requested on merits). See, generally, Lumbers v. Fretz (1928), 63 O.L.R. 190 (C.A.). 


\section{Ultra Vires.}

The election of directors beyond the numbers allowed in the letters patent, ${ }^{134}$ or even fewer than provided for, ${ }^{133}$ is considered to be ultra vires; and a personal action will be in order. A similar principle should apply for memorandum and articles companies, in light of the importance attached to matters in the articles regarding directors. ${ }^{136}$

What is to be done with Kelly v. Electrical Construction Co. ${ }^{137}$ and Watt v. Commonwealth Petroleum Ltd.? ${ }^{138}$ More particularly, what of the rationale behind the rule in Foss v. Harbottle, requiring action in the company's name? The argument is that, if the majority desire the action, then they can bring it in the company's name; but, if they do not, then upsetting the election will be futile anyway, because the majority can proceed to re-elect their candidate. ${ }^{139}$ This view is a persuasive one, particularly when the complainants are clearly in a minority and the irregularity is a minor one committed inadvertently.

However, one must remember that a shareholder's rights do not depend upon whether he is in the majority. He has a right to say, "Whether I vote in the majority or the minority you shall record my vote, as that is a right of property belonging to my interest in this company, and if you refuse to record my vote I will institute proceedings against you to compel you." 140 While this may be futile on the particular occasion, upsetting resolutions and elections on such bases will have a deterrent effect and prevent practices which may lead to manipulation and abuse.

There is one situation in which a minority action will have a practical as well as a deterrent effect. Since many intra-corporate battles are fought by proxy, the balance of power may shift several times; and a group which held a majority at the time of an election, ${ }^{1.11}$ only to have it nullified by irregular procedures, may subsequently have become a minority, unable to use the company name in an action. In such circumstances, a minority action is justified. The law has provided a time within which the sides may marshal support, and to allow a group to nullify this through "sharp practices" would merely lead to delay and uncertainty. Of course, if the temporary majority does not represent the true majority of the shareholders and is created only accidentally, then the court may refuse to force a director on a company. This was the situation in Harben v. Phillips, ${ }^{12}$ where the plaintiffs were elected only because of the temporary and accidental invalidity of some proxy votes. However, once a director is properly elected, ordinarily only a special resolution can remove him; and a bare majority can neither stop him from acting $^{143}$ nor oust him and prevent any litigation by refusing the use of the company name. ${ }^{144}$

\footnotetext{
134 McKenna v. Spooner Oil Ltd., [1934] 1 W.W.R. 255 (S.C. Alta.).

135 Sherker v. Rudner (1911), 39 Q.R. 44 (S.C.).

$136 \mathrm{Cf}$. Bottomley's Case (1880), $16 \mathrm{Ch}$. 681 (forfelture of shares by four, instead of minimum five, directors on board held invalid).

137 (1908), 16 O.L.R. 232.

138 [1938] 4 D.L.R. 701 (Alta. C.A.).

139 The "futllity" argument referred to ante, notes 4 and 43

140 Pender v. Lushington (1877), 6 Ch. D. 70. 81.

140 Pender v. Lushington the type of situation under discussion occurred in British Asbestos Co. v. Boyd, [1903] 2 Ch. 439, where a bare majority of shareholders insufficient to remove the directors $(1,344$ votes to 1,116$)$ challenged their position in the hope of creating a vacancy for their candidate. They lost on the merits.

144 This, again, is the rule that a majority cannot confirm an act which can only validly be done or sanctioned, not by a simple, but by some special majority: ante, $n$. 45.
} 
Of course, it is only rarely that a member in a minority situation will sue; usually it will be the majority bringing an action. Should they be required to use the company name? There are three reasons why that should not be necessary. Firstly, as a matter of principle, if the rights infringed are personal, then each individual should be able to enforce them even if he is in the majority. Secondly, to require use of the company name may lead to an unnecessary dispute over its use between the majority and the directors. It is generally accepted that the board has control of the company management including the use of its name in litigation. ${ }^{145}$ There is, however, one case ${ }^{140}$ in which the majority was allowed to use the name over the objection of the directors; and the practice where the authority to use the company's name has been challenged is to refer it to a meeting of the shareholders. ${ }^{147}$ In addition, it has been decided that, where the issue involved is a challenge to the directors themselves, they cannot use the position being disputed to prevent action in the company's name. Thus, in Sasko-Wainwright Oil \& Gas Ltd. v. Old Stettler Oil Ltd., ${ }^{148}$ where the capacity of the directors to authorize use of the company's name was dependent upon the validity of their election, the Appellate Division of the Supreme Court of Alberta held that where
... the question of capacity is an issue in the appeal, even though an indirect one, the court should not dispose of the appeal on the ground of want of capacity to bring the appeal. If the appellant were successful in the appeal, the question of capacity or authority would disappear. $1+0$

However, other issues may arise where, for instance, there is only one director being challenged and the balance of the board declines to allow use of the company's name. Although the shareholders might succeed, there are so many permutations and combinations possible that it would be advisable to avoid completely all dispute on this matter, by allowing personal actions.

This view is supported by the third reason, which is a negative one, for allowing suit without use of the company's name. If it is the majority bringing the action (and particularly if it is in representative form so that all are bound), ${ }^{150}$ the "futility" argument disappears. Surely the question of costs would be sufficient to deter any member who "loves litigation"1:1 from running to the courts over every trifle.

\section{Election of Directors.}

\section{CONCLUSION}

In light of the foregoing discussion it can be said to be very difficult to justify the decisions in Kelly v. Electrical Construction Co. ${ }^{152}$ and

\footnotetext{
145 John Shaw \& Sons (Salford) Ltd. v. Shaw, [1935] 2 K.B. 113 (C.A.); Macson Development Co. v. Gordon (1959), 19 D.L.R. (2d) 465,470

140 Marshall's Valve Gear Co. v. Manning, Wardle \& Co., [1909] 1 Ch. 267.

147 Macson Development Co. v. Gordon, ante, $n$. 145, at 469 , and cases cited there.

148 (1956-57), 20 W.W.R. (N.S.) 613 (Aita. C.A.).

140 Id. at 618, per Johnson, J.A. (Italics supplied). See also Colonial Assurance Co. v Smith (1912), 2 W.W.R. 699; Standard Construction Co. v. Crabb (1914), 7 W.W.R. 719 (individual directors have no authority to speak for the company); and British Asbestos Co. v. Boyd, [1903] 2 Ch. 439 (action to challenge defendent directors allowed in company's name, but name struck out, and then issue lost).

1 :o Price v. Rhondda U.D.C. [1923] 2 Ch. 372. See Lloyd, Actions Instituted By or Against Unincorporated Bodies (1949), 12 Modern L.R. 409, on representative actions generally. 151 The principle in MacDougall v. Gardiner (1875). I Ch. D. 13, was partly designed to prevent multiplicity of actions by members "who love litigation": per Mellish. I.J. at 25. Sed quaere whether, in light of costs, the danger of a cantankerous member abusing the legal process is greater than that of legerdemain at meetings.
}

132 (1908), 16 O.L.R. 232. 
Watt v. Commonwealth Petroleum Ltd. ${ }^{153}$ They are defective in almost every aspect. Firstly, their origin is unsatisfactory, since Mozley v. Alston and Hattersley v. Earl of Shelburne do not support the propositions derived from them. ${ }^{154}$ Secondly, their adoption of the first interpretation of the rule in MacDougall v. Gardiner ${ }^{155}$ completely disregards any concept of a member's rights either to have only properly elected directors in office ${ }^{\mathbf{1 5 0}}$ or to have proper procedures followed in convening and conducting meetings. ${ }^{157}$ Finally, there is an overwhelming mass of case law ${ }^{158}$ which conflicts, not only in principle, but, in some decisions, on the facts as well.

There is, of course, some scope for the viewpoint expressed in the Kelly and Watts cases, since not every procedural slip should render proceedings invalid. But there is a definite area, and one which it is submitted should be broadly construed, in which procedural safeguards are of the essence of shareholder protection. On their facts, the Kelly and Watt cases go beyond the bounds of what the law should allow.

However, in any future problem of this kind it will be impossible to predict with certainty the outcome, since the courts do have two lines of authority from which they may choose. It is perhaps more true of this area of procedural irregularity than any other to say, as Professor Gower has, "that the courts have ceased to be moved by pure questions of principle but have instead given weight to the practical advantages of the Foss v. Harbottle rule."1so

\section{Disqualification of Directors.}

On the other hand, the shareholder's right to challenge the qualifications of a director seems firmly established by Theatre Amusement Co. v. Stone and other authority, ${ }^{100}$ and it is unlikely that the courts would recant on this vital matter.

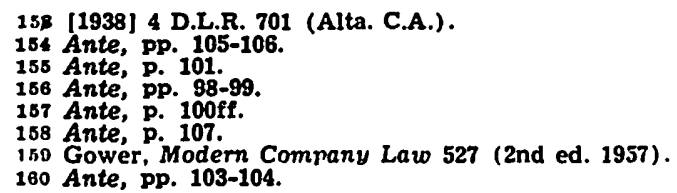

